\title{
Tradescantia pallida L. (Commelinaceae) influences the activity of oviposition and feeding of Plutella xylostella (Lepidoptera: Plutellidae)
}

\author{
Tradescantia pallida L. (Commelinaceae) influencia a atividlade de oviposição e alimentação de \\ Plutella xylostella (Lepidoptera: Plutellidae) \\ Tradescantia pallida L. (Commelinaceae) influye en la actividad de oviposición y alimentación de
} Plutella xylostella (Lepidoptera: Plutellidae)

Received: 06/26/2021 | Reviewed: 07/04/2021 | Accept: 07/08/2021 | Published: 07/18/2021

Aline do Nascimento Rocha
ORCID: https://orcid.org/0000-0003-0590-0780
Federal University of Grande Dourados, Brazil
E-mail: aline_2402@ @otmail.com
Emerson Machado de Carvalho
ORCID: https://orcid.org/0000-0002-4865-6784
Techno-Science and Innovation Training Center Federal University of Southern Bahia, Brazil
E-mail: carvalho.em@gmail.com
Juliana Rosa Carrijo Mauad
ORCID: https://orcid.org/0000-0003-3901-1105
Federal University of Grande Dourados, Brazil
E-mail: julianacarrijo@ufgd.edu.br
Rosilda Mara Mussury
ORCID: https://orcid.org/0000-0002-8961-9146
Federal University of Grande Dourados, Brazil
E-mail: mussuryufgd@gmail.com

\begin{abstract}
Diamondback moth represents one of the major Brassicaceae plagues and the main current control method relies on the agrotoxins use. The search for alternative phytosanitary control methods demonstrates that the vegetal extracts have broadly studied and now represent a relevant option to control insects-plagues in small cultivation areas. Was evaluated the effect of the aqueous extract Tradescantia pallida 10\% in oviposition and the feeding preference of Plutella xylostella, in laboratory conditions. That plant does not present herbivory reports, which raises the hypothesis of representing an efficient control alternative. P. xylostella couples introduced in experimentation cages for 10 days, to assess the activity of oviposition, being exposed to the botanic extract in the feeding and the oviposition substrate, with the eggs average number per day and fertility being assessed. To assess feeding, two tests developed: free choice and no choice of food source during 48 hours of evaluation. The results indicate that the aqueous T. pallida extract changes the oviposition activity of $P$. xylostella, reducing the average number of eggs per day and the fertility. It was also possible to observe the non-preference, regarding feeding, for substrates that were treated with the extract. The results observed in the study can contribute to amplify the small producers decision-making processes and the involved sectors regarding the choice of supplies that respect environmental and human health.
\end{abstract}

Keywords: Bioinsecticide; Diamondback moth; Deterrence; MIP.

\section{Resumo}

Diamonthback month é uma das principais pragas das brassicáceas e o principal método de controle atualmente é o uso de agrotóxicos. A procura por métodos alternativos de controle fitossanitário, evidencia que os extratos vegetais, vem sendo amplamente estudado e representa uma opção relevante no controle de insetos-praga em pequenas áreas de cultivo. Foi avaliado o efeito do extrato aquoso de Tradescantia pallida $10 \%$ na atividade de oviposição e preferência alimentar de Plutella xylostella, em condições de laboratório. Essa planta não apresenta relatos de herbivoria, o que levanta a hipótese de representar uma alternativa eficaz de controle. Casais de P. xylostella foram introduzidos em gaiolas de experimentação, durante 10 dias, para avaliação da atividade de oviposição e expostos ao extrato botânico na alimentação e no substrato de oviposição, sendo avaliado o número médio de ovos diários e fertilidade. Para avaliar a alimentação foram desenvolvidos dois testes: com e sem chances de escolha de fonte alimentar num período de 48 horas de avaliação. Os resultados indicam que o extrato aquoso de T. pallida altera a atividade de oviposição de P. xylostella, reduzindo o número médio de ovos diários e a fertilidade. Também foi possível observar a não preferência de alimentação por substratos tratados com o extrato. Os resultados observados no estudo podem 
contribuir para ampliar as tomadas de decisão dos pequenos produtores e os setores envolvidos em relação a escolhas de insumos que respeitem a saúde ambiental e humana.

Palavras-chave: Bioinseticida; Traça das crucíferas; Deterrência; MIP.

\section{Resumen}

El mes de diamonthback es una de las principales plagas de las Brassicaceas y el principal método de control en la actualidad es el uso de pesticidas. La búsqueda de métodos alternativos de control fitosanitario muestra que los extractos de plantas han sido ampliamente estudiados y representan una opción relevante en el control de plagas de insectos en pequeñas áreas de cultivo. El efecto del extracto acuoso de Tradescantia pallida al 10\% sobre la actividad de oviposición y la preferencia alimenticia de Plutella xylostella se evaluó en condiciones de laboratorio. Esta planta no tiene reportes de herbivoría, lo que plantea la hipótesis de que representa una alternativa de control eficaz. Se introdujeron parejas de P. xylostella en jaulas experimentales durante 10 días para evaluar la actividad de oviposición y se expusieron al extracto botánico en el alimento y en el sustrato de oviposición, y se evaluó el número promedio de huevos diarios y la fertilidad Para evaluar la alimentación se desarrollaron dos pruebas: con y sin posibilidades de elegir la fuente de alimento en un período de evaluación de 48 horas. Los resultados indican que el extracto acuoso de T. pallida altera la actividad de oviposición de P. xylostella, reduciendo el número promedio de huevos diarios y la fertility. También se pudo observar la no preferencia de alimentación por sustratos tratados con el extracto. Los resultados observados en el estudio pueden contribuir a ampliar la toma de decisiones de los pequeños productores y los sectores involucrados en relación a la elección de insumos respetuosos con el medio ambiente y la salud humana.

Palabras clave: Biopesticida; Diamonthback; Disuasión; MIP.

\section{Introduction}

The damages by Plutella xylostella (Linnaus 1758) (Lepidoptera: Plutellidae) have been generating significant economic losses in the vegetables production (Barros et al. 1993; Haseeb et al. 2004; Zalucki et al. 2012). The agrotoxins is the most commonly used method for the immediate control of these insect actions, due to their practicality and quickness action with the plague population (Talekar \& Shelton 1993; Valadares et al., 2020). However, the inadequate use of agricultural supplies contributed to the resistance development of the $P$. xylostella to diverse products used in agricultural corps (Castelo \& Melo 2002; Thuler et al. 2007). Resulting in harmful effects for public health and the environment (Boiça Jr. et al. 2005), discussions about the possible impact caused by the agrotoxins use have been amplified by different society sectors, such as public health and environmental protection agencies, which look for alternatives to mitigate this problem (Lawler 2017).

Due to the economic impact caused by that moth species in brassica crops, adding to the problems related to control measures, it becomes necessary to study alternative methods that adapt to the plagues integrated management. The use of vegetable extracts allows strategies that produce a smaller environmental impact, better biodiversity use, and reduction of damages in non-target populations (Saleem et al. 2020). Such technique is for small producers and/or organic producers, due to its lower financial cost and the aggregation value to the final product, since besides applying good production practices, they align with ONU sustainable development goals (Agenda 2030) and the One Health principles (Cook et al. 2004). Research about plant extracts reported insecticide properties such as mortality and feeding deterrence (Zhang et al. 2001; Chandrashekharaiah et al. 2015; Liu et al. 2015; Matias da Silva et al. 2017), larvicide effects (Hikal et al. 2017; Ferreira et al. 2020), reduction of fecundity (Ferreira et al. 2020), repellence (Boiça Jr. 2013), morphological and physiological changes in P. xylostella (Pan et al. 2016; Peres et al. 2017; Couto et al. 2019), and infertility in adults (Gu et al. 2004).

Secondary metabolites synthesized by plants can contain terpenes, flavonoids, alkaloids, rotenoids, pyrethroids, phenols, and other related compounds that can severely interfere in the metabolism of other organisms, creating variable impacts, such as repellence, feeding and oviposition deterrence, and sterilization (Medeiros 1990; Lancher 2000). Those compounds presented the advantages of selectivity and not toxic to the environment (Isman 2006). However, a lack of studies about the potential as an insecticide for the vast majority of the species, which implies the need to develop research to find new alternatives might contribute to global, sustainable and productive development.

The plant Tradescantia pallida (Rosa) D. R. Hunt var. purpurea belongs to a type of herbaceous perennial plants from 
the Commelinaceae family (Hunt 1975; Watson \& Dallwitz 1992). In a recent study, Menegazzo et al., (2020) performed the chemical analysis of the aerial portion of T. pallida, identifying 32 compounds in the essential oil, with the main constitutes being spathulenol (19.56\%), caryophyllene oxide (18.84\%), b-caryophyllene (13.65\%), and a-copaene (6.08\%). That plant does not represent reports of herbivory, which raises the hypothesis of representing a control alternative given broad occurrence and how easy it is to handle. The goal of this work was to assess the effect of the aqueous extract of T. pallida $10 \%$ on the oviposition activity of $P$. xylostella.

\section{Methodology}

\subsection{Creation and maintenance of Plutella xylostella}

The individuals used in experiments are from the Laboratory of Plant-Insect Interaction (LIIP) of Biological and Environmental Sciences Faculty, located in Universidade Federal University of Grande Dourados, South Mato Grosso, Brazil. The individuals used for the following experiences were from the third generation and had been kept under controlled temperature conditions $\left(25 \pm 2{ }^{\circ} \mathrm{C}\right)$, relative humidity $(60 \pm 5 \%)$, and photoperiod (12 hours).

The larvae fed with organic leaves from Brassica oleracea L.var. acephala DC. and during the adult stage were fed with hydrated honey (Peres et al. 2017), from Apis mellifera ( $1 \mathrm{~mL}$ of honey: $9 \mathrm{~mL}$ of water).

\subsection{Collect the botanic material and preparing the aqueous extract}

Completely expanded leaves of Tradescantia pallida were gathered in the vegetable garden of Federal University of Grande Dourados, in the Municipality of Dourados-MS (22 $\left.{ }^{\circ} 11^{\prime} 42.8^{\prime \prime S} 54^{\circ} 56^{\prime} 06.7^{\prime \prime W}\right)$, during the period between $7 \mathrm{am}$ to $9 \mathrm{am}$. The leaves were dried in a greenhouse by air forced circulation for four days with a maximum temperature of $45^{\circ} \mathrm{C}\left( \pm 1^{\circ} \mathrm{C}\right)$. After that period, the leaves were ground with a cutting mill (Model SL-32 type Willey) until thin dust was obtained (Adapted from Couto et al. 2019).

To get an aqueous extract of $T$. pallida (ETP) with a $10 \%$ concentration (weight /volume), $10 \mathrm{~g}$ of the dust material were used per $100 \mathrm{~mL}$ of distilled water. After manual agitation, it lied quietly for 24 hours in a refrigerated environment $\left(5^{\circ} \mathrm{C}\right)$. After this period, the liquid was strained with a paper filter and the resulting substance was used in the experiments. An authorization for collecting botanical material was granted by Council of Genetic Heritage Management/ National System for the Management of Genetic Heritage and Associated Traditional Knowledge (CGEN/MMA/SISGEN), under the number A719505.

\subsection{Tests of oviposition preference}

Pupae removed from the stock creation and unitarily deposited in glass test tubes with a screwcap lid (13x100mm) until the emerging of the adult to perform sexing and organize couples. 24 hours later, couples submitted to six different treatment types for 10 days (Table 1 ).

20 couples were placed in oviposition cages $(9.6 \times 9.8 \mathrm{~cm})$, fed with cotton moistened with hydrated honey and for the oviposition substrate were used cabbage discs over disks of paper filter $(9 \mathrm{~cm}$ of diameter) (Figure 1). The type of feeding, as well as the substrates offered to couples in each test, described in table 1 and replaced on a daily basis. Later, the eggs were counted every day for 4 days during tests no chance for choosing (adapted from Couto et al. 2019). For the tests no chance for choosing (1,2,3 and 4), the average of hatched eggs on the cabbage disks was obtained, as well as the fertility of such egg s for hatching on up to 4 days after being lay. The averages compared by test $t$ and the standard deviation calculated for each treatment. 
Figure 1. Schematic representation of the used methodology for the feeding application and oviposition treatments.

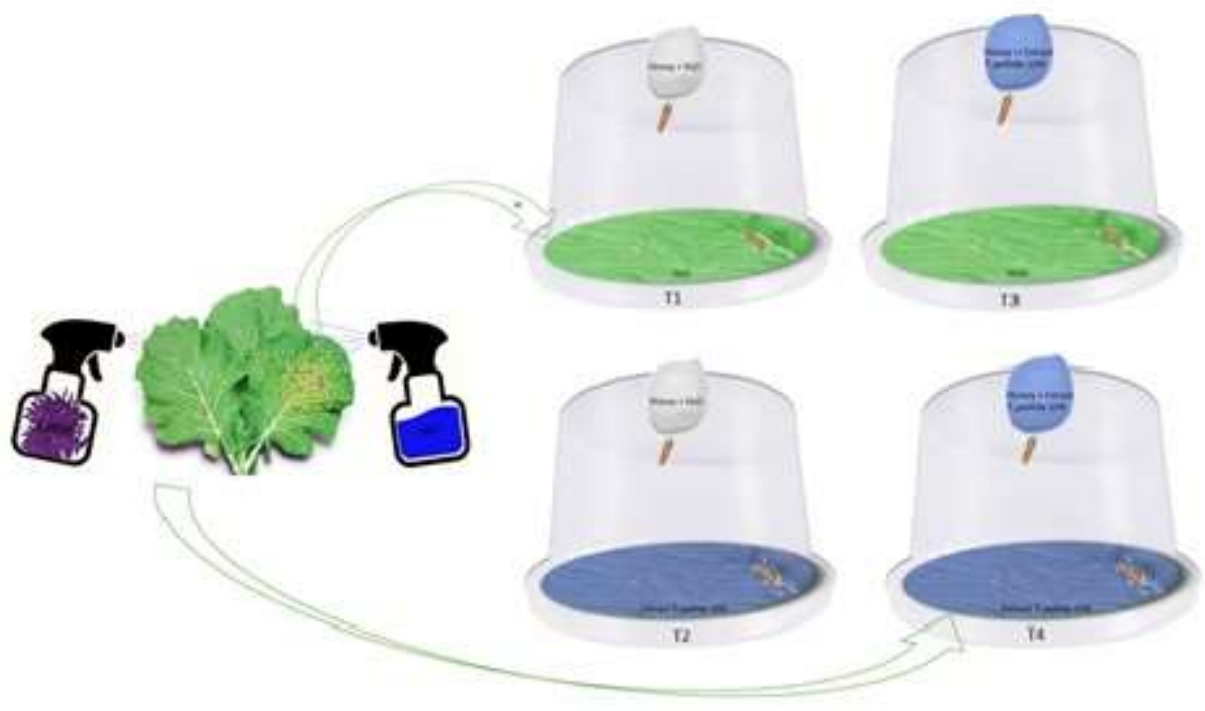

Source: Authors.

To determine the oviposition preference in the tests free choice, it was calculated the index of preference of oviposition according to the methodology by Kogan \& Goeden (1970), and it is classified as a stimulant for laying eggs if the index is higher than 1 , neutral if equal to 1 , and as a deterrent for laying eggs if smaller than 1 , through the formula: IP = 2A/(M+A), where: $\mathrm{A}=$ number of eggs on the treated discs; $\mathrm{M}=$ number of eggs in the non-treated disks. The test $\mathrm{t}$ was performed $(\mathrm{p} \leq 0.05)$ on the statistic program Past 3.0.

The eggs fertility was determined by the number of eggs that hatched and originated viable larvae on the cabbage disks. On the tests free choice, the acquired data were analyzed by the test $\mathrm{T}(\mathrm{p} \leq 0.05)$ on the statistics program Past 3.0 .

Table 1. Description of the different treatments used to verify the effects of the extract of Tradescantia pallida.

\begin{tabular}{|c|c|c|c|}
\hline Treatment & $\begin{array}{l}\text { Chance for } \\
\text { choosing }\end{array}$ & Oviposition substrate & Offered food (2mL/Day) \\
\hline 01 & No & 1 Disk of organic cabbage treated with distilled water & Solution of hydrated honey (10\%) \\
\hline $\mathbf{0 2}$ & No & 1 Disk of organic cabbage treated with ETP $(10 \%)$ & Solution of hydrated honey (10\%) \\
\hline $\mathbf{0 3}$ & No & 1 Disk of organic cabbage treated with distilled water & $\begin{array}{l}\text { Solution (1:1): of hydrated honey } \\
\qquad(10 \%) \text { and ETP }(10 \%)\end{array}$ \\
\hline 04 & No & 1 Disk of organic cabbage treated with ETP $(10 \%)$ & $\begin{array}{r}\text { Solution (1:1): of hydrated honey } \\
\qquad(10 \%) \text { and ETP }\end{array}$ \\
\hline 05 & Yes & $\begin{array}{l}2 \text { Disks of organic cabbage treated with distilled water and } 2 \text { disks of } \\
\text { organic cabbage treated with }(10 \%) \text { intercalated. }\end{array}$ & Solution of hydrated honey (10\%) \\
\hline 06 & Yes & $\begin{array}{l}2 \text { Disks of organic cabbage treated with distilled water and } 2 \text { disks of } \\
\text { organic cabbage treated with ETP }(10 \%) \text { intercalated. }\end{array}$ & $\begin{array}{l}\text { Solution (1:1): of hydrated honey } \\
\qquad(10 \%) \text { and ETP }(10 \%)\end{array}$ \\
\hline
\end{tabular}

Source: Authors. 


\subsection{Feeding preference Test}

For the feeding preference tests, the used larvae went through a fast period of 12 hours.

2.4.1. Feeding preference test no choice for choosing $-P$. xylostella maggot of the $3^{\text {rd }}$ instar was disposed at the center of a Petri dishes with a diameter of $15 \mathrm{~cm}$, the bottom of the dishes had been covered by a paper filter circle, slightly moistened with distilled water to avoid the dryness of the foliar disks. Cabbage disks with $4 \mathrm{~cm}$ of diameter were treated with an $T$. pallida $10 \%$ aqueous extract or with distilled water (control) and arranged in separately dishes.

The experience was constituted by 25 repetitions of each treatment. The assessments were performed after 48 hours of exposition. The assessed variable was the foliar consumption, obtained from the difference between the initial area of the leave and the remaining area after the larvae fed, measured using the software ImageJ (Schneider et al., 2012). The data were analyzed by the $\mathrm{F}$ test and the averages of foliar consumption were compared using the test $\mathrm{T}(\alpha<0,05)$ for two samples, presuming different variances, comparing the absolute values $\left(\mathrm{cm}^{2}\right)$ using the software Past 3.22. In the end, the percentage of the final weight was analyzed, obtained by subtracting the initial weight to the final weight for the 25 repetitions, with the data being transformed into percentages.

2.4.2. Test of feeding preference with free choice for choosing - cabbage disks with $4 \mathrm{~cm}$ of diameter, with the application of the aqueous extract of T. pallida (10\%) and distilled water (control), were placed in Petri dishes (120 x 20mm) and distributed in a crossed and equidistant way. The experiment was composed of 10 repetitions with 5 subsamples with a larva each. The assessments were made 48 hours after the exposition of the larvae to the extract, with the consumed foliar area of the disks being measured using the software ImageJ (Schneider et al. 2012).

The effect produced by the vegetal extract assessed using the index of feeding preference (Kogan \& Goeden, 1970), being classified as bacteriophage stimulant if the index was higher than 1, neutral if equal to 1, and bacteriophage deterrent if the index was lower than 1 , through the formula: $\mathrm{IP}=2 \mathrm{~A} /(\mathrm{M}+\mathrm{A})$, where: $\mathrm{A}=$ consumed area of the treated disks; $\mathrm{M}=$ consumed areas of the non-treated disks. The data regarding foliar consumption in the treatments and the index of preference compared by the test $\mathrm{T}(\alpha<0.05)$.

\section{Results}

\subsection{Oviposition}

The couples subjected to the treatment with resources considered as optimal (Treatment 01: no exposition) for development, in the tests no chance to choosing, presented the biggest activity of oviposition, considering the number and fertility of eggs observed, during the experimentation period that lasted for 10 days (Figure 2A) when compared to other treatments (Figure 2B, C, D, E).

All tests no chance for choosing in which larvae had some exposition degree to the aqueous extract of T. pallida a $10 \%$ (ETP) presented a lower oviposition activity, as well as lower fertility of the eggs (Table 2). 
Figure 2. Oviposition activity ) and fertility of the eggs $(\mathbf{\Delta})$ of Plutella xylostella were observed daily in the 4 treatments no chance of choosing for 10 days, in laboratory conditions: T: $25 \pm 1^{\circ} \mathrm{C}$, U.R.: $65 \pm 5 \%$, photo phase: 14 hours. A: Treatment 01; B: Treatment 02; C: Treatment 03; D: Treatment 04.

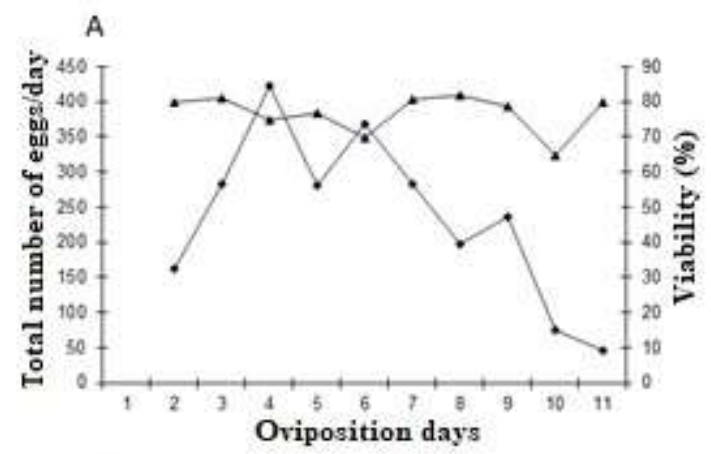

C

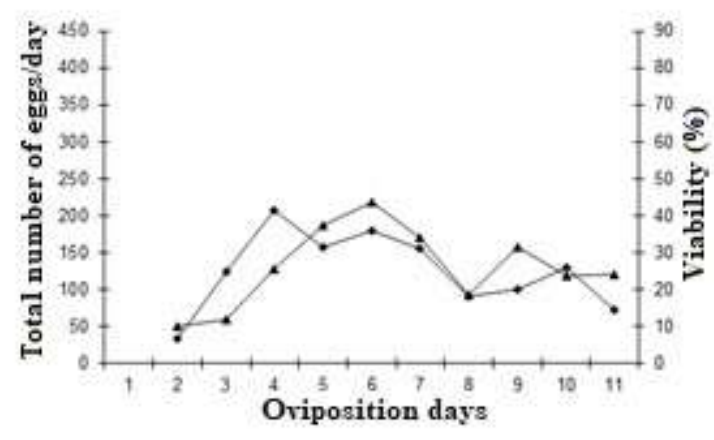

B

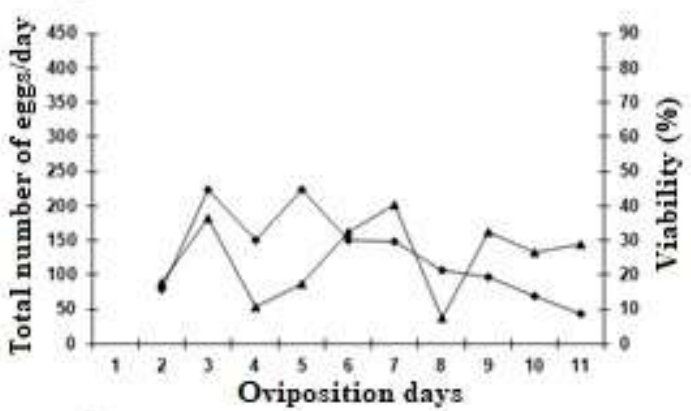

D

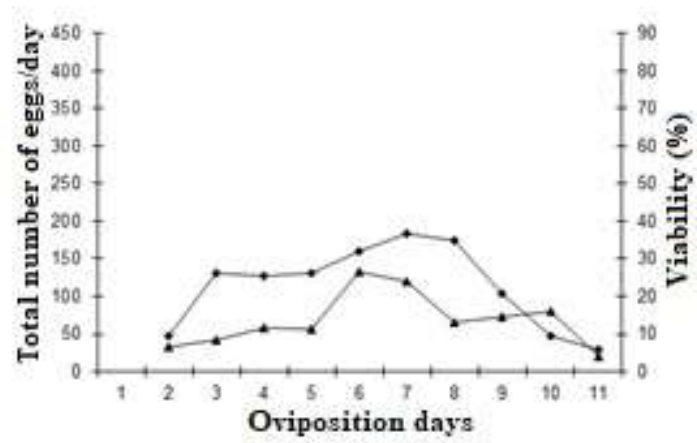

Source: Authors.

Table 2. The average number of viable eggs ( \pm standard deviation) of Plutella xylostella exposed to different treatments, no choice for choosing, with the aqueous extract of Tradescantia pallida at $10 \%$. T: $25 \pm 1^{\circ} \mathrm{C}$, U.R.: $65 \pm 5 \%$, photo phase: 14 hours.

\begin{tabular}{lll}
\hline Treatment * & Eggs/Female & Viable eggs \\
\hline Treatment 01 & $93.72 \pm 12.08 \mathrm{a}$ & $68.35 \pm 10.37 \mathrm{a}$ \\
Treatment 02 & $33.11 \pm 7.58 \mathrm{~b}$ & $17.10 \pm 5.57 \mathrm{~b}$ \\
Treatment 03 & $39.08 \pm 12.04 \mathrm{~b}$ & $18.72 \pm 6.98 \mathrm{~b}$ \\
Treatment 04 & $16.05 \pm 5.44 \mathrm{~b}$ & $6.83 \pm 2.00 \mathrm{~b}$ \\
C.V. $(\%)$ & 47.38 & 54.71 \\
\hline
\end{tabular}

*Averages followed by the same letter on the column do not differ between themselves according to the Tukey test at a level of $1 \%$ of probability $(\mathrm{p}<0.05)$. Source: Authors.

In tests with free choice (Treatment 05 and Treatment 06), it appears that in the experimental period the highest oviposition activity occurred in the control discs (Figure $3 \mathrm{~A}, \mathrm{~B}$ ), and conversely, the eggs average number in the treatments with free choice were lower in discs treated with extract (Table $3 \mathrm{C}$ ). The oviposition preference index are all below 1 , indicating oviposition potential throughout the sample period (Figure 3D). 
Figure 3. Total number of eggs produced by Plutella xylostella during 10 days of experiments in tests free choice of choosing the oviposition substrate. A: Treatment 05 - Intercalated discs with and without ETP (10\%) fed with hydrated honey solution (10\%); B: Treatment 06 - Intercalated discs with and without ETP (10\%) with solution feeding (1:1): hydrated honey (10\%) and ETP (10\%). C: Mean number of eggs oviposited by Plutella xylostella ( \pm standard error bars) in free choice tests for T5 and T6 (water and ETP). Means followed by different uppercase letters differ from each other in treatment 05 (T05) and different lowercase letters differ in treatment 06 (T06) by the T test. D: Oviposition preference index between oviposition substrates with and without extract of treatments 05 and 06 ( \pm standard error bars).
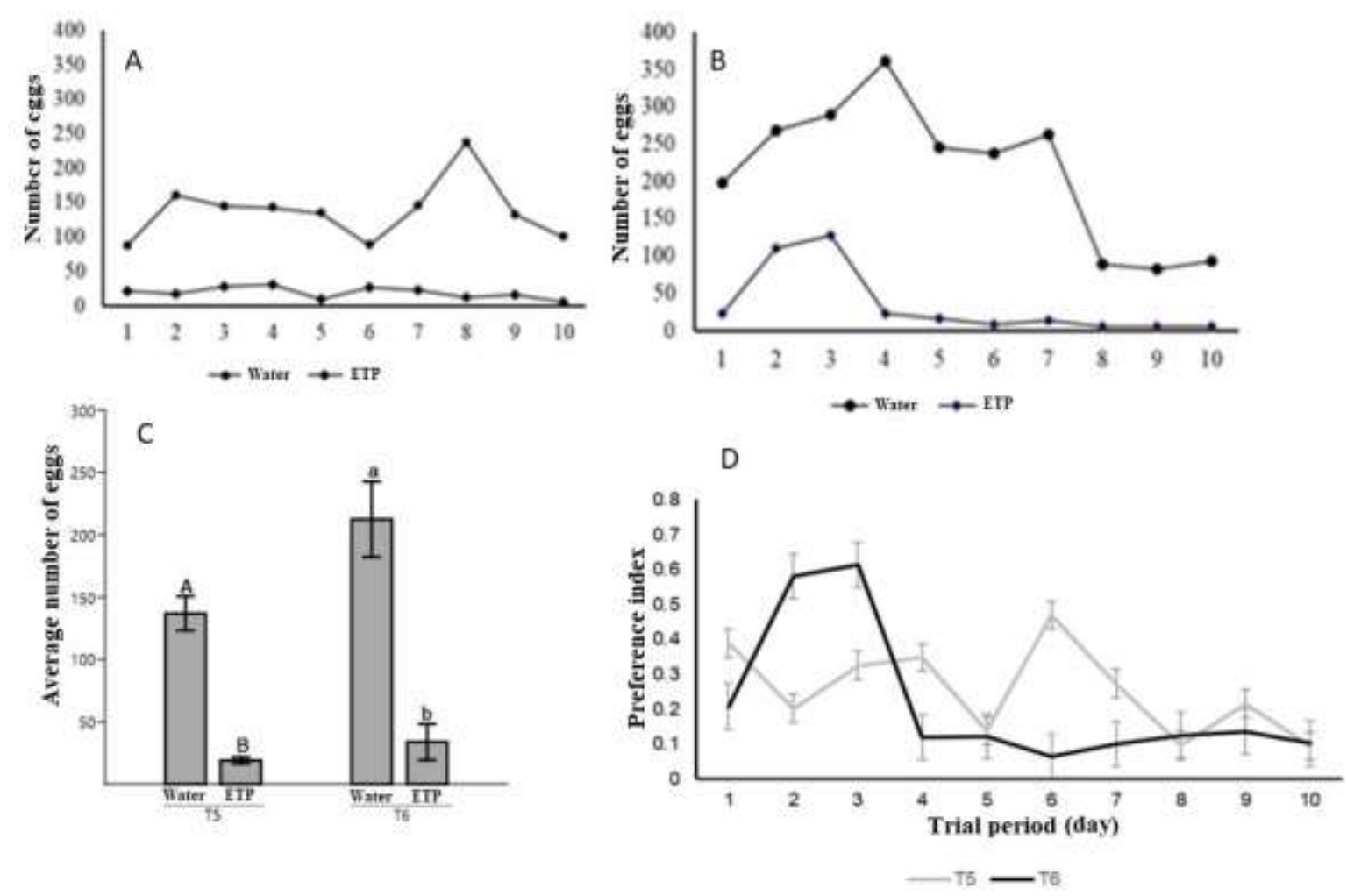

Source: Authors.

\subsection{Feeding}

There was a difference between the control and ETP $10 \%$ treatments in the test with no chance of choice by the F test, (4.1152; $\mathrm{p}=0.0009)$ with a variance of 0.34 (control) and 0.083 (extract). By the $\mathrm{T}$ test $(\mathrm{t}=2.044 ; \mathrm{p}=0.034)$, therefore, the null hypothesis is rejected, as the control treatment differs from the extract. Plutella xylostella larvae consume a smaller leaf area of B. oleraceae in the treatment with $10 \%$ T. pallida aqueous extract, differing from the control (Figure 4). 
Figure 4. Mean leaf area consumed by Plutella xylostella in test free choice and no choice. Means with different letters in the treatment (free choice and no choice) indicate statistical difference by the $t$ test.

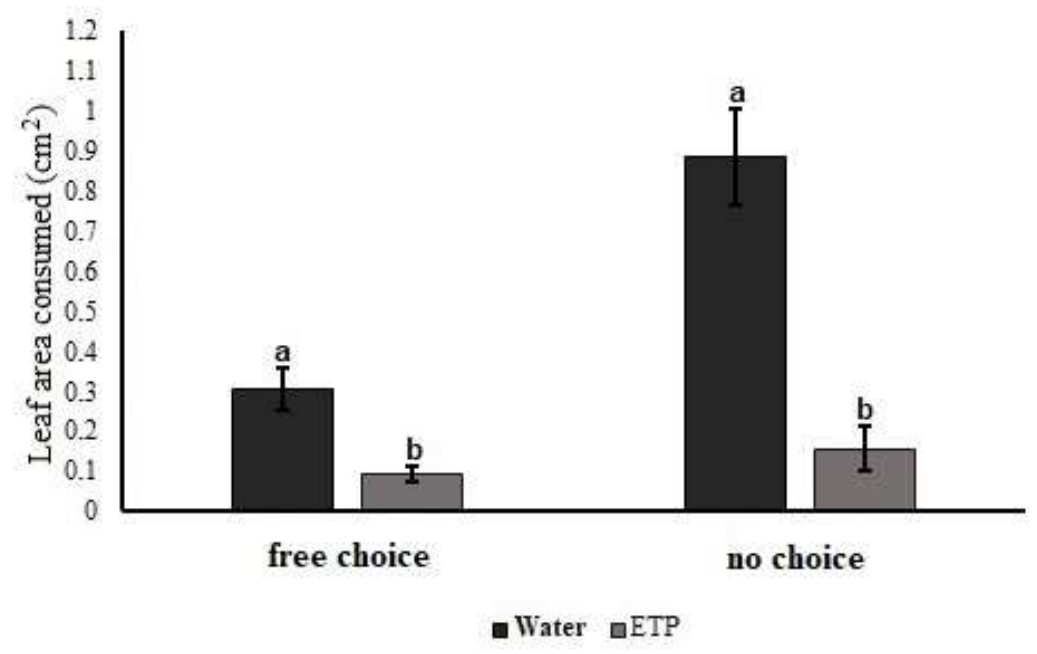

Source: Authors.

It observed that individuals fed by disk with extract showed greater weight loss when compared to the control (Figure 5).

Figure 5. Percentage of gain, loss, weight indifferent and Plutella xylostella death after the experimental period in the no choice tests. A: control; B: ETP $10 \%$.

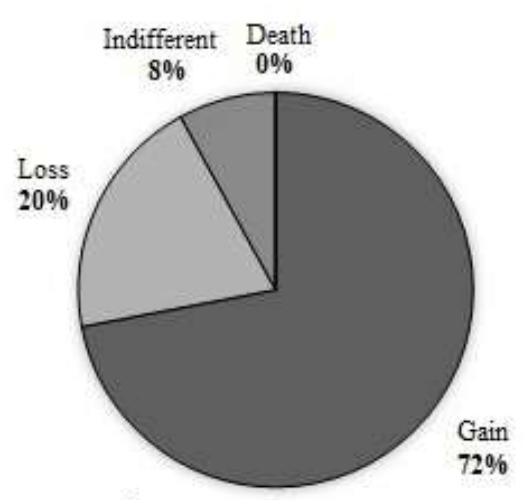

A

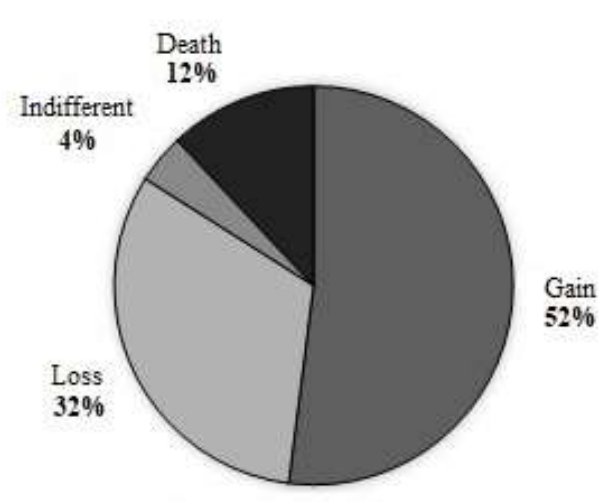

B

Source: Authors.

In the test with free choice, when comparing the control and extract treatments, there was a difference by the $\mathrm{F}$ test $(\mathrm{F}=7.56 ; \mathrm{p}=0.005)$ and also by the $\mathrm{t}$ test $(\mathrm{t}=3.78 ; \mathrm{p}=0.0014)$. The observed IP value classifies the extract as phagodeterrente (Table 3).

When the choice tests were analyzed together, in general, it was found that, regardless of the type of test, the larva prefers control discs much more than when ETP $10 \%$ is present. 
Table 3. Mean and standard error (SE) of the food preference index (PI) and leaf consumption of the larval stage of Plutella xylostella, submitted to tests without the use of $10 \%$ Tradescantia pallida aqueous extract (control) and with use (extract).

$\mathbf{P I} \pm \mathbf{S E}$

Leaf consumption $\left(\mathrm{cm}^{2}\right)$

control

ETP $10 \%$

Free choice

$0.524 \pm 0.09$

$0.31 \pm 0.054 \mathrm{~A}$

$0.09 \pm 0.019 \mathrm{~B}$

Phagodeterrent

No choice

$0.60 \pm 0.12 \mathrm{~A}$

$0.28 \pm 0.05 \mathrm{~B}$

Temperature: $25 \pm 1^{\circ} \mathrm{C}, \mathrm{RH}: 70 \pm 10 \%$, photophase: $12 \mathrm{~h}$. Means followed by the same capital letter in the line differ, through the $\mathrm{t}$ student test. Source: Authors.

\section{Discussion}

The monitoring of the $T$. pallida $10 \%$ aqueous extracts effectiveness on $P$. xylostella evaluated and we verified potential for controlling the species. The literature presents the antimicrobial potential in gram-positive and gram-negative bacteria (Tan et al. 2014), antioxidants (Silva et al. 2015) and anticancer activities against cervical cancer cell lines (Li et al. 2017), with positive results for tests performed with ethanolic and methanolic extracts. Through these results, we can also include ovipodeterrent and phagodeterrent action to this plant species.

The use of plants with insecticide effect is an important method in pest control, as it reduces economic and environmental impacts. Studies referring to plants with insecticidal potential are becoming increasingly important, as they allow association with other control methods, such as chemical and biological (Marangoni et al., 2013), as long as they are properly monitored. Oxygenated sesquiterpene and hydrocarbons are the predominant classes (93.52\%) in the essential oil of T. pallida (Menegazzo et al. 2020). These elements can also be present in the aqueous extract in different proportions, being responsible for the observed characteristics.

The oviposition activity, throughout the experimental period, observed with greater intensity when compared to other treatments where ETP not applied, a fact also evidenced in the tests with free choice, where, even with exposure to ETP, the number of eggs was higher in the control substrates. The insect's chemosensory system is capable of detecting volatile odors (olfactory system) and non-volatile chemicals (gustatory system) (Kaupp 2010; Robertson 2019). Taste sensilas can be found in the following structures: antennae, labial palps, spirothrombus, legs, wings and ovipositors (Zhang et al. 2010) and help to discriminate between attractive and deterrent components of the host plant (Weiss et al. 2011; Xu \& Anderson 2015). Here, we infer the presence of elements with deterrent effects on ETP, due to non-preference for treated substrates, in oviposition and feed preference tests.

In this study, in addition to the oviposition substrate, ETP was also inserted in the food solution offered to the insect, increasing the exposure level to ETP. It is known that adults need to feed with nectar before mating and laying eggs (Romeis \& Wäckers 2000; Zhang et al. 2010) and thus, it was observed in the tests a lower oviposition activity and egg fertility in the treatments with exposure of the insect to ETP, with emphasis when the food and substrate offered contained ETP. The toxicity of ETP in eggs, making them unviable, is an important result, since the existence of a lipid layer inside the corium of lepidopteran eggs retains toxic substances, preventing them from reaching the embryo (Torres et al. 2006).

In general, $P$. xylostella larvae in the presence of $10 \%$ ETP, besides the phagodeterrente effect, also had the lowest weight gain and death when compared to the control larvae. Note that aqueous extracts and ethanol extracts of S. terebinthifolius exhibited 
a phagodeterrent effect on P. xylostella, reducing leaf consumption, due to the presence of secondary metabolites (Couto et al. 2019), including tannins and flavonoids isolated in S. terebinthifolius leaves (A. Salvi Júnior, cited by Johann et al. 2010).

Despite being efficient in most situations, synthetic insecticides can cause environmental and food contamination, in addition to contributing to biological imbalance due to the elimination of non-target organisms (Hernández \& Vendramim, 1996; Valadares et al. 2020). Therefore, the use of plant extracts, associated with other practices, is an option for integrated pest management as they are obtained from renewable sources (reflecting on the low financial cost) and effectiveness in low concentrations (Ware \& Whitacre 2004; Koul et al. 2008; Prates et al. 2019) and in line with global interdisciplinary sustainability requirements (Cook et al., 2004). In this work, we emphasize the ovipotential and phagodeterrent action of $T$. pallida extract $10 \%$ under laboratory conditions, and we encourage future fieldwork to investigate the results under natural conditions.

\section{Conclusion}

The $10 \%$ Tradescantia pallida aqueous extract alters the oviposition and feeding activity of Plutella xylostella. The effects observed under controlled laboratory conditions are: reduced oviposition activity and egg fertility; lower weight and leaf consumption. Thus, it appears that the use of T. pallida aqueous extracts offers an opportunity to integrate the perspective of biodiversity conservation and human needs, by developing economically viable alternative solutions that do not harm the environment. We encourage works that use this product in semi-field situations to demonstrate the feasibility of applying and protecting agricultural crops against Diamondback moth.

\section{Acknowledgments}

The authors thank the Federal University of Grande Dourados for the logistical support and National Council for the Improvement of Higher Education - Brazil (CAPES) for providing scholarship to the first author and the foundation for the development of Education, Science and Technology of Mato Grosso do Sul (FUNDECT), for the resource provided by the process $\mathrm{n}^{\circ} 71 / 711.130 / 2018$.

\section{References}

Barros, R., Alberto Júnior, I. B., Oliveira, A. J., Souza, A. C. F., \& Lopes, V. (1993). Controle químico da traça das crucíferas, Plutella xylostella (L.) (Lepidoptera: Plutellidae), em repolho. Anais da Sociedade Entomológica do Brasil, 22, 463-469.

Boiça Júnior, A. L., Janini, J. C.; Souza, B. H. S. de, \& Rodrigues, N. E. L. (2013). Efeito de cultivares de repolho e doses de extrato aquoso de nim na alimentação e biologia de Plutella xylostella (Linnaeus) (Lepidoptera: Plutellidae). Bioscience Journal, 29(1), $22-31$.

Castelo Branco, M. \& Melo, C. A. de. (2002) Resistência a abamectin e cartap em populações de traça-das-crucíferas. Horticultura Brasileira, $20,541-543$. https://doi.org/10.1590/S0102-05362002000400005

Chandrashekharaiah, M., Kandakoor, S. B., Gowda, G. B., Kammar, V., \& Chakravarthy, A. K. (2015). Nanomaterials: a review of their action and application in pest management and evaluation of DNA-tagged particles. New horizons in insect science: Towards sustainable pest management, 113-126 https://doi.org/10.1007/978-81-322-2089-3_12

Cook, R. A., Karesh, W. B. \& Osofsky, S. A. (2004). The Manhattan Principles on 'One World, One Health'. Conference Summary. New York. Wildlife Conservation Society, New York. http://www.oneworldonehealth.org/sept2004/owoh_sept04.html

Couto, I. F. S., Verza, S., Valente, F. I., Senna, B., Souza, S. A., Mauad, M., \& Mussury, R. M. (2019) Botanical Extracts of the Brazilian Savannah Affect Feeding and Oviposition of Plutella xylostella (Linnaeus, 1758) (Lepidoptera: Plutellidae). Journal of Agricultural Science, 11, 322. https://doi.org /10.5539/jas.v9n11p99

Ferreira, E. A., de Souza, S. A., Domingues, A., Da Silva, M. M. M., Padial, I. M. P. M., de Carvalho, E. M., Cardoso, C. A. L., da Silva, S. V., \& Mussury, R. M. (2020) Phytochemical Screening and Bioactivity of Ludwigia spp. in the Control of Plutella xylostella (Lepidoptera: Plutellidae). Insects. 11(9), 596. https://doi.org/10.3390/insects11090596 
Gu, H. (2009). Cold Tolerance and Overwintering of the Diamondback Moth (Lepidoptera: Plutellidae) in Southeastern Australia. Environmental Entomology, 38(3), 524-529. https://doi.org 10.1603/022.038.0303

Haseeb, M., T. X. Liu \& W. A. Jones. (2004). Effects of selected insecticides on Cotesia plutellae, endoparasitoid of Plutella xylostella. BioControl, 49, 3346. https://doi.org/10.1023/B:BICO.0000009377.75941.d7

Hernández, C. R. \& Vendramim, J. D. (1996) Toxicidad de extractos acuosos de Meliaceae em Spodoptera frigiperda (Lepidoptera: Noctuidae). Manejo Integrado Plagas, 14-22.

Hikal, W. M., Baeshen, R. S., SAID-AL, A. H. L, \& Hussein, A. H. (2017). Botanical insecticide as simple extractives for pest control. Cogent Biology, 3(1), 1404274 https://doi.org/10.1080/23312025.2017.1404274

Hunt, D. R. (1975) The reunion of Setcreasea and Separotheca with Tradescantia American Commelinaceae: I. Kew Bull, 30(3):443-458. https://doi.org/10.2307/4103068

Isman, M. B. (2015) A renaissance for botanical insecticides? Pest Management Science, 71, 1587-1590. https://doi.org/10.1002/ps.4088

Isman, M. B. (2006) Botanical insecticides, deterrents, and repellents in modern agriculture and an increasingly regulated world. Annual Review of Entomology, 51(1), 45-66. https://doi.org/10.1146/annurev.ento.51.110104.151146

Johann, S., Cisalpino, P. S., Watanabe, G. A., Cota, B. B., De Siqueira, E. P., Pizzolatti, M. G. Zani, C. L., \& De Resende, M. A. (2010) Antifungal activity of extracts of some plants used in Brazilian traditional medicine against the pathogenic fungus Paracoccidioides brasiliensis. Pharmaceutical Biology, $48,388-96$. https://doi.org/10.3109/13880200903150385

Kaupp, U. B. (2010) Olfactory signalling in vertebrates and insects: differences and commonalities. Nature Reviews Neuroscience, 11, 188-200. https://doi.org/10.1038/nrn2789

Kogan, M. \& Goeden, R. D. (1970). The Host-Plant Range of Lema trilineata daturaphila (Coleoptera: Chrysomelidae). Ann Entomoll Soc Am 63, 11751180. doi:10.1093/aesa/63.4.1175

Koul, O., Walia, S., \& Dhaliwal, G. S. (2008). Essential oils as green pesticides: potential and constraints. Biopesticides International. 4:63-84.

Lancher, W. (2000). Ecofisiologia Vegetal. São Carlos-SP: Rima, 519p.

Li, C.Y., Zhang, Z. C., Mao, J. Y., Shi, L. F., Zheng, Y., \& Quan, J. L. (2017) Preparation of Tradescantia pallida mediated zinc oxide nanoparticles and their activity against cervical cancer cell lines. Tropical Journal of Pharmaceutical Reserach. 16(3):494-500. DOI: 10.4314/tjpr.v16i3.1

Liu, X., Wang, H. Y., Ning, Y. B., Qiao, K. \& Wang, K. Y. (2015). Resistance selection and characterization of chlorantraniliprole resistance in Plutella xylostella (Lepidoptera: Plutellidae). Journal of Economic Entomology, 108(4), 1979-1985. https://doi.org/10.1093/jee/tov098

Marangoni, C., de Moura, N. F., \& Garcia, F. R. M. (2013). Utilização de óleos essenciais e extratos de plantas no controle de insetos. Revista de Ciências Ambientais, 6(2), 92-112. http://dx.doi.org/10.18316/870

Matias da Silva, R., Fioratti, C. A. G., Silva, G. B., Cardoso, C. A. L., Miranda, L. O., Mauad, M., \& Mussury, R.M. (2017). Antibiose do extrato foliar de Duguetia furfuracea sobre Plutella xylostella (Lepidoptera: Plutellidae). In Temas Atuais em Ecologia Comportamental e Interações. Anais do II BecIntBehavioral Ecology and Interactions Symposium, 1st ed.; Calixto, E.S., Toreza-Silingardi, H.M., Eds.; Editora Composer: Uberlândia, Brasil, 2017; Volume 1, pp. 52-69. ISBN 978-85-8324-057-0.

Medeiros, A. R. M. (1990) Alelopatia: importância e suas aplicações. Horti Sul, 1(3) 27-32.

Menegazzo, R. F., Bortolucci, W. D. C., de Oliveira, H. L. M., Menegazzo, A. W., Gonçalves, J. E., Fernandez, C. M. M., \& Lopes, A. D. (2020). Chemical composition of Tradescantia pallida (Rose) DR Hunt var. purpurea Boom (Commelinaceae) essential oil. Natural Product Research, 1-5. https://doi.org/10.1080/14786419.2020.1765341

Pan, L., Ren, L., Chen, F., Feng, Y., \& Luo, Y. (2016) Antifeedant activity of Ginkgo Biloba secondary metabolites against Hyphantria cunea larvae: Mechanisms and applications. Plos One, 11, 155682. https://doi.org/10.1371/journal.pone.0155682

Peres, L. L. S., Sobreiro, A. I., Couto, I. F. S., Silva, R. M., Pereira, F. F., Heredia-Vieira, S. C., Cardoso, C. A. L., Mauad, M., Scalon, S. P. Q., Verza, S. S. \& Mussury, R.M. (2017) Chemical compounds and bioactivity of aqueous extracts of Alibertia spp. in the control of Plutella xylostella L. (Lepidoptera: Plutellidae). Insects, 8, 125. https://doi.org/10.3390/insects8040125

Prates, L. H. F., Faroni, L. R. A., Heleno, F. F., Queiroz, M. E. L. R., Sousa, A. H., \& Silva, M. V. A. (2019). Eugenol diffusion coefficient and its potential to control Sitophilus zeamais in rice. Sci Rep. Aug; 9:11161, 10.1038/s41598-019-47562-1

Robertson, H. M. (2019). Molecular evolution of the major arthropod chemoreceptor gene families. Annual Review Entomology. 64, $227-242$. https://doi.org/10.1146/annurev-ento-020117-043322

Romeis, J., \& Wäckers, F.L., (2000). Feeding responses by female Pieris brassicae butterflies to carbohydrates and amino acids. Physiological Entomology, 25, 247-253. https://doi.org/10.1046/j.1365-3032.2000.00188.x

Saleem, M. H., Ali, S., Rehman, M., Rana, M. S., Rizwan, M., Kamran, M., Imran, M., Riaz, M., Soliman, M. H., \& Elkelish. A. (2020). Influence of phosphorus on copper phytoextraction via modulating cellular organelles in two jute (Corchorus capsularis L.) varieties grown in a copper mining soil of Hubei Province, China. Chemosphere, 248. 126032. https://doi.org/10.1016/j.chemosphere.2020.126032

Schneider, C. A., Rasband, W. S., \& Eliceiri, K. W. (2012). NIH Image to ImageJ: 25 years of image analysis. Nature Methods, 9(7), 671-675. doi:10.1038/nmeth.2089 
Research, Society and Development, v. 10, n. 8, e57610817583, 2021

(CC BY 4.0) | ISSN 2525-3409 | DOI: http://dx.doi.org/10.33448/rsd-v108.17583

Silva, A., Silva, A. M., Masson, R., Mota, R. D., Costa, N. C., Ribeiro, E. E., Loureiro, W. A. S., \& Figueiredo, P. (2015) Evaluation of antimicrobial activity of the Tradescantia pallida Munt plant (Taboquinha Roxa). Brazilian Journal of Medicinal Plants. 17(3), 374-378. https://doi.org/10.1590/1983084X/12_188

Souza, S. A., Couto, I. F. S., Silva, M. P., Cardoso, C. A. L., Scalon, S. P. Q., Ferreira, F. F., Carvalho, E. M., \& Mussury, R. M. (2019) Aqueous extracts of species of the genus Campomanesia (Myrtaceae) affect biological characteristics of Plutella xylostella (Linnaeus, 1758) Lepidoptera: Plutellidae. Journal of Agricultural Science, 11, 20-28 10.5539/jas.v11n5p334

Talekar, N. S., \& Shelton, A. M. (1993). Biology, ecology and management of the diamondback moth. Annual Review of Entomology, 38, $275-301$. https://doi.org/10.1146/annurev.en.38.010193.001423

Tan, J. B., Yap, W. J., Tan, S. Y., Lim, Y. Y., \& Lee, S. M. (2014) Antioxidant content, antioxidant activity, and antibacterial activity of five plants from the Commelinaceae family. Antioxidants, 3(4), 758-769. https://doi.org/10.3390/antiox3040758

Torres, A., Júnior, A. L. B., Medeiros, C. A. M., \& Barros, R. (2006). Efeito de extratos aquosos de Azadirachta indica, Melia azedarach e Aspidosperma pyrifolium no desenvolvimento e oviposição de Plutella xylostella. Bragantia, 65(3), 447-457. https://doi.org/10.1590/S0006-87052006000300011

Thuler, R. T. D., Bortoli, S. A., \& Barbosa, J. C. (2007). Eficácia de inseticidas químicos e produtos vegetais ao controle de Plutella xylostella. Científica, 35(2), 166-17. http://dx.doi.org/10.15361/1984-5529.2007v35n2p166+-+174

Valadares, A. A., Alves, F., Galiza, M., \& Silva, S. P. (2020). Agricultura familiar e abastecimento alimentar no contexto do Covid-19: uma abordagem das ações públicas emergenciais. Disponível em: http://repositorio.ipea.gov.br/handle/11058/9996. Acesso em: 03 de fev 2021.

Ware, G. W., \& Whitacre, D. M. (2004). Introducción a los insecticidas. In: The Pesticide Book. 6. ed. Ohio: Meister Pro Information Resources. 194 p.

Watson, L., Dallwitz, M. J. \& Johnston, C. R. (1986). Grass Genera of the World: 728 Detailed Descriptions from an Automated Database international. Australian Journal of Botany, 34(2) 223 - 230 https://doi.org/10.1071/BT9860223

Weiss, L. A., Dahanukar, A., Kwon, J. Y., Banerjee, D., \& Carlson, J. R. (2011). The molecular and cellular basis of bitter taste in Drosophila. Neuron. 69, 258-272. https://doi.org/10.1016/j.neuron.2011.01.001

Xu, W., \& Anderson, A. (2015). Carbon dioxide receptor genes in cotton bollworm Helicoverpa armigera. The Science of Nature, 102, 11. https://doi.org/10.1007/s00114-015-1260-0

Zalucki, M. P., Shabbir, A., Silva, R., Adamson, D., Liu, S. S., \& Furlong, M. J. (2012). Estimating the economic cost of one of the world's major insect pests, Plutella xylostella: Just how long is a piece of string? Journal of Economy Entomology, 104(4), 1115-1129. https://doi.org/10.1603/EC12107

Zhang, Y. F., Loon, J. J. A. van, \& Wang, C. Z. (2010). Tarsal taste neuron activity and proboscis extension reflex in response to sugars and amino acids in Helicoverpa armigera (Hübner). Journal of Experimental Biology. 213, 2889-2895. https://doi.org/10.1242/jeb.042705

Zhang, X. Y., Jie, H., YE, C. Y., \& Xue, Y. (2001) Monitoring on the resistance of diamond back moth to abamectin and field control experiments in Yunnan. Journal of Huazhong Agricultural University, 20, 426-430. 